\title{
Neutralization of interleukin-38 exacerbates coxsackievirus B3-induced acute myocarditis in mice
}

Yimin Xue ${ }^{1,2,4}$, Mingguang Chen ${ }^{1,2}$, Qian Chen ${ }^{1,2}$, Tingfeng Huang ${ }^{1,2}$, Qiaolian Fan ${ }^{1,2}$, Fenghui Lin ${ }^{1,2}$, Jun $\mathrm{Ke}^{1,3,4}$ and Feng Chen ${ }^{1,3,4^{*}}$ (D)

\begin{abstract}
Background: Interleukin (IL)-38, a novel member of the IL-1 family, has been reported to be involved in several diseases associated with viral infection. However, the expression and functional role of IL-38 in acute viral myocarditis (AVMC) have not been investigated.

Methods: Male BALB/c mice were treated with intraperitoneal (i.p.) injection of coxsackievirus B3 (CVB3) for establishing AVMC models. On day 7 post-injection, the expression of IL-38 and IL-36R (IL-36 receptor) were measured. Mice were then treated with i.p. injection of mouse Anti-IL-38 Antibodies (Abs) for neutralization of IL-38. The survival, bodyweight loss, cardiac function, and myocarditis severity of mice were recorded. The percentages of splenic Th1 and Th17 cells, the expression levels of Th1/Th17-related master transcription factors (T-bet and RORyt) and cytokines were determined by flow cytometry, RT-qPCR, and ELISA, respectively. Cardiac viral replication was further detected.

Results: The mRNA and protein expression levels of IL-38 in myocardium and serum, as well as cardiac IL-36R mRNA levels were significantly elevated in mice with AVMC. Increased IL-38 levels were negatively correlated with the severity of AVMC. Neutralization of IL-38 exacerbated CVB3-induced AVMC, as verified by the lower survival rate, impaired cardiac function, continuous bodyweight loss, and higher values of HW/BW and cardiac pathological scores. In addition, neutralization of IL-38 suppressed Th1 cells differentiation while promoted Th17 cells differentiation, accompanied by decreased T-bet mRNA expression and increased RORyt expression. Down-regulation of IFN- $\gamma$ and up-regulation of IL-17, TNF-a, and IL-6 mRNA and protein expression levels in myocardium and serum were also observed in the IL-38 neutralization group. Furthermore, neutralization of IL-38 markedly promoted cardiac viral replication.
\end{abstract}

Conclusions: Neutralization of IL-38 exacerbates CVB3-induced AVMC in mice, which may be attributable to the imbalance of Th1/Th17 cells and increased CVB3 replication. Thus, IL-38 can be considered as a potential therapeutic target for AVMC.

Keywords: Acute viral myocarditis, IL-38, Th1 cells, Th17 cells, Coxsackievirus B3

*Correspondence: fislchenfeng@126.com

1 Shengli Clinical Medical College of Fujian Medical University, Fuzhou 350001, Fujian, People's Republic of China

Full list of author information is available at the end of the article

\section{Background}

Acute viral myocarditis (AVMC), a common inflammatory myocardial disease, is one of the leading causes of acute-onset heart failure and sudden death among young patients [1,2]. Some patients with AVMC may progress into chronic myocarditis, causing continuous destruction of cardiomyocytes and the initiation of remodeling otherwise in a credit line to the material. If material is not included in the article's Creative Commons licence and your intended use is not permitted by statutory regulation or exceeds the permitted use, you will need to obtain permission directly from the copyright holder. To view a copy of this licence, visit http://creativecommons.org/licenses/by/4.0/. The Creative Commons Public Domain Dedication waiver (http://creativecommons.org/publicdomain/zero/1.0/) applies to the data made available in this article, unless otherwise stated in a credit line to the data. 
process [3]. Coxsackievirus B3 (CVB3), a member of the Picornaviridae family, has been identified as the most common pathogen for AVMC [4]. Although a multitude of studies have demonstrated that the major pathogenesis of AVMC is excessively uncontrolled inflammatory responses triggered by myocardial damage following viral infection, the direct attack of the virus on cardiomyocytes is also considered a critical component for AVMC development and progression [5, 6]. Accumulating evidence has revealed that both $\mathrm{T}$ helper (Th) 1 and Th17 cells play a crucial role in the early immune reaction to CVB3 infection [7-9]. However, up to now, the treatment of AVMC is still mostly restricted to supportive measures as there is no specific treatment for the disease. It is essential to clarify the fundamental mechanisms responsible for AVMC.

Interleukin (IL)-38 (IL-1F10), a newly identified cytokine of the IL-1 family, is located in the IL-1 family cluster on chromosome 2 next to the genes encoding IL-1 receptor antagonist (IL-1Ra) and IL-36Ra, and shares nearly $41 \%$ homology with IL-1Ra and $43 \%$ homology with IL-36Ra [10]. Similar to other IL-1 family members, IL-38 lacks a signal peptide and has no caspase-1 consensus cleavage site $[10,11]$. It mediates its biological effects via the specific receptor IL-36R, a partial receptor antagonist of IL-36. Therefore, IL-38 plays an antagonistic role in the pro-inflammatory effects of IL-36 cytokines,

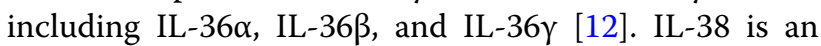
abundant, ubiquitously expressed cytokine, which can be secreted by fibroblast-like synoviocytes, peripheral blood mononuclear cells (PBMCs), keratinocytes, epithelial cells, and various immune cells, such as B cells, natural killer (NK) cells, macrophages, and dendritic cells (DCs) $[11,12]$. Abnormal expression of IL-38 has been found in many inflammatory diseases, including rheumatoid arthritis (RA), allergic asthma (AA), and systemic lupus erythematosus (SLE) [13-15]. In addition, elevated serum IL-38 levels at baseline can be used to predict virological response in telbivudine-treated patients with chronic hepatitis B [16]. Moreover, Gao and Conti have reported that IL-38 is a potential therapeutic cytokine that inhibits inflammation in viral infections, including those caused by the influenza virus and Coronavirus-19 $[17,18]$. These findings indicate that IL-38 may play an important role in the pathogenesis of diseases associated with viral infection. However, the expression and functional role of IL-38 in AVMC are still largely unknown.

To tentatively tap this field, we investigated the expression of IL-38 and IL-36R in vivo in mice with AVMC. The percentages of splenic Th1 and Th17 cells, the expression levels of Th1/Th17-related master transcription factors (T-bet and RORyt) and cytokines, and cardiac viral replication were determined. Additionally, neutralizing
Anti-IL-38 Antibodies (Abs) were given to AVMC mice to further explore the effect of IL-38 on myocarditis.

\section{Methods \\ Mice}

Specific pathogen-free grade wild-type male BALB/c mice aged 6 weeks (production license: SCXK (Zhe) 2019-0001) were purchased from the Zhejiang Vital River Laboratory Animal Technology Co., Ltd. (Zhejiang, China). Mice were housed under standard pathogen-free conditions at the Experimental Animal Center (Fujian Academy of Medical Sciences, Fuzhou, Fujian, China). All studies were approved by the Animal Experimentation Ethics Committee of Shengli Clinical Medical College of Fujian Medical University (SYXK: 2016-0004). The experimental methods were performed in accordance with the approved guidelines.

\section{CVB3 infection}

The CVB3 (Nancy strain, a kind gift from Prof. Weifeng Wu of Guangxi Medical University) was produced in monolayers of HeLa cells (ATCC, CCL-2) and stored at $-80{ }^{\circ} \mathrm{C}$. The virus titer, determined based on a standard plaque-forming unit (PFU) assay on HeLa cells, was $1 \times 10^{8} \mathrm{PFU} / \mathrm{ml}$. Male BALB/c mice aged 6 weeks were infected by intraperitoneal (i.p.) injection of $200 \mu$ phosphate-buffered saline (PBS) containing $2 \times 10^{5} \mathrm{PFU}$ of CVB3 to establish the AVMC models.

\section{Induction of AVMC}

A total number of $28 \mathrm{BALB} / \mathrm{c}$ mice were randomly assigned into two groups as follows: (1) Control group $(\mathrm{n}=10)$ containing mice treated with i.p. injection of PBS (200 $\mu$ l per mouse); (2) AVMC group $(\mathrm{n}=18)$ comprising mice administered CVB3. The day of i.p. injection was defined as day 0 . All surviving mice were sacrificed on day 7 after CVB3 infection. The heart, spleen, and blood were collected.

\section{Neutralization of IL-38}

To elucidate the role of IL-38 in vivo, Anti-IL-38 Abs were used to neutralize IL-38 in mice. We performed a dose-response experiment of Anti-IL-38 Abs in vivo based on the dose previously reported in the studies [19, 20]. As shown in Additional file 1: Figure S1, mice were treated with three different doses of Anti-IL-38 Abs (25, 50 , or $75 \mu$ g per mouse) by i.p. injection on day 0 and day 4 after CVB3 infection. It was observed that Abs dose of 50 or $75 \mu \mathrm{g}$ per mouse per injection was more effective in neutralizing IL-38 expression in vivo than that of $25 \mu$ g per mouse per injection (both $P<0.01$ ), while there was no significant difference in effectiveness between the doses of 50 and $75 \mu \mathrm{g}$ per mouse per injection (both 
$P>0.05)$. Since the Abs dose of $50 \mu \mathrm{g}$ per mouse per injection was sufficient to effectively neutralize IL-38 expression in vivo, this dose was used for subsequent experiments. A total of $55 \mathrm{BALB} / \mathrm{c}$ mice were randomly divided into four groups: 1) IL-38 neutralization (IL-38N) group [mice treated with i.p. injection of Anti-IL-38 Abs ( $50 \mu \mathrm{g}$ per mouse, on day 0 and day $4, \mathrm{n}=15$ ) after CVB3 infection]; 2) IgG group [mice treated with i.p. injection of $\operatorname{IgG}_{2 \mathrm{~A}}$ isotype control ( $50 \mu \mathrm{g}$ per mouse, on day 0 and day $4, \mathrm{n}=15$ ) after CVB3 infection]; 3) PBS group [mice treated with i.p. injection of PBS $(50 \mu \mathrm{g}$ per mouse, on day 0 and day $4, \mathrm{n}=15$ ) after CVB3 infection]; and 4) Sham group [untreated mice administered an i.p. injection of PBS on day 0 and day $4(n=10)$ ]. Mouse AntiIL-38 Abs and $\operatorname{IgG}_{2 \mathrm{~A}}$ isotype control were obtained from R\&D Systems, Minneapolis, MN, USA. The survival rates and bodyweight changes were monitored daily until day 7. The spleen and heart were removed aseptically to be measured on day 7 post CVB3 infection. Before mice were killed, the cardiac function was assessed and then serum was collected for the study.

\section{Transthoracic echocardiography}

The cardiac function of mice was evaluated non-invasively on day 7 by transthoracic echocardiography using a Vevo2100 Ultrasound System (Fujifilm VisualSonics, Bothell, WA, USA) equipped with a $40 \mathrm{MHz}$ transducerphased-array transducer. Mice were anesthetized with i.p. administration of sodium pentobarbital $(1 \%, 50 \mathrm{mg} / \mathrm{kg})$ and immobilized in a supine position. The parameters of heart function were recorded in two-dimensional mode, and left ventricular parasternal long-axis views were obtained in $\mathrm{M}$-mode imaging at the papillary muscle level. Ventricular parameters, including left ventricular end-systolic diameter (LVESD), left ventricular end-diastolic diameter (LVEDD), fractional shortening (FS), and ejection fraction (EF) were measured and analyzed using a standard formula as described previously [21]. The sonographer was unaware of the group allocations.

\section{Histopathological examination}

Heart ventricular tissues fixed in 10\% phosphate-buffered formalin were embedded in paraffin, and sections $(5 \mu \mathrm{m}$ thick) were stained with hematoxylin and eosin (H\&E) to quantify the severity of inflammation. Histopathological changes were viewed using a Leica DM2000 LED microscope (Leica, Wetzlar, Germany). Cardiac pathological scores were graded by two independent researchers in a blinded manner according to the following scoring method: 0 , no inflammation; $1,1-5$ distinct mononuclear inflammatory foci with involvement of $5 \%$ or less of the cross-sectional area; 2,>5 distinct mononuclear inflammatory foci, or involvement of over $5 \%$ but not over $20 \%$ of the cross-sectional area; 3 , diffuse mononuclear inflammation involving over $20 \%$ of the area, without necrosis; and 4, diffuse inflammation with secondary necrosis and acute inflammation [22].

\section{Immunohistochemistry}

For immunohistochemistry, the streptavidin-biotin complex method was applied. The staining was performed using a Streptavidin-Biotin Complex kit (Boster, Wuhan, Hubei, China) according to the manufacturer's instructions. The obtained sections of heart ventricular tissues were deparaffinized using xylene, followed by rehydration using alcohol and washing with PBS. The sections were microwaved in citrate buffer for $15 \mathrm{~min}$ to retrieve antigen and then treated with $3 \%$ hydrogen peroxide for $10 \mathrm{~min}$ to block endogenous peroxidase. The sections were treated with $10 \%$ goat serum (Boster) for $30 \mathrm{~min}$ at room temperature to block the binding of nonspecific Abs. Rabbit anti-mouse IL-38 polyclonal antibody (1:200, Bioss, Beijing, China) was added to the sections, and incubation was performed overnight at $4{ }^{\circ} \mathrm{C}$. Histochemical reactions were then developed using 3, 3-diaminobenzidine (Sigma-Aldrich, St. Louis, MO, USA) as the chromogenic substrate for peroxidase. Negative controls replaced the primary antibody with nonimmune goat serum, with all other steps performed as above. The semiquantitative analysis of IL-38 deposition was performed using Image-Pro Plus 6.0 software (Media Cybernetics, Bethesda, MD, USA). For each slide, 5 randomly chosen fields at $400 \times$ magnification were photographed and analyzed by two independent pathologists uninformed of the experimental grouping to measure the integrated optical density (IOD).

\section{Flow cytometric analysis}

The spleen from each mouse was removed aseptically and dispersed through nylon mesh to generate a singlecell suspension. After red blood cells removal by Red Blood Cell Lysing Buffer (Sigma-Aldrich), the splenic mononuclear cells were washed twice in RPMI 1640 (Invitrogen, Carlsbad, CA, USA) and resuspended in RPMI 1640 medium with 10\% FBS (Invitrogen). Cells were stimulated with phorbol myristate acetate $(25 \mathrm{ng} /$ $\mathrm{ml}$, Sigma-Aldrich) and ionomycin $(1 \mu \mathrm{g} / \mathrm{ml}$, SigmaAldrich) for $5 \mathrm{~h}$ at $37^{\circ} \mathrm{C}$ in the presence of GolgiPlug $\left(1 \mu \mathrm{l} / 10^{6}\right.$ cells, BD Biosciences, Breda, the Netherlands). After stimulation, cells were collected, washed, and stained with phycoerythrin cyanine-5-conjugated antimouse CD4 (eBioscience, San Diego, CA, USA). Cells were stained intracellularly with anti-IFN- $\gamma$, or IL-17 mouse Abs conjugated with Alexa Fluor ${ }^{\circledR} 488$, or phycoerythrin after fixation and permeabilization according to the manufacturer's instructions (eBioscience), and 
then measured by flow cytometry using a FACSCalibur flow cytometer (BD Biosciences). The data were analyzed using the FCS Express 7 Research Edition software (DeNovo Software, Glendale, CA, USA).

\section{Quantitative real-time PCR (RT-qPCR)}

Total RNA was extracted from cardiac tissue using TRIzol reagent (Invitrogen), followed by transcription into cDNA with a PrimeScript ${ }^{\mathrm{TM}}$ RT reagent kit (TaKaRa, Dalian, Liaoning, China) according to the instructions provided by the manufacturer. Primers for IL-38, IL36R, IFN- $\gamma$, IL-17, TNF- $\alpha$, IL-6, T-bet, ROR $\gamma$ t, CVB3, and the housekeeping gene $\beta$-actin were designed with the Primer Premier 5.0 software (Premier Biosoft, Palo Alto, CA, USA) and are shown in Table 1. RTqPCR was performed in an ABI 7500 Sequence Detection System (Applied BioSystems, Foster City, CA, USA) using a SYBR ${ }^{\circledR}$ Premix Ex Taq $^{\text {TM }}$ II kit (TaKaRa) for detection. The thermal cycling conditions were: initial denaturation at $94{ }^{\circ} \mathrm{C}$ for $3 \mathrm{~min}$, followed by 40 cycles of $94{ }^{\circ} \mathrm{C}$ for $30 \mathrm{~s}, 60^{\circ} \mathrm{C}$ for $30 \mathrm{~s}$ and $72{ }^{\circ} \mathrm{C}$ for $30 \mathrm{~s}$. The relative expression of target genes was normalized to $\beta$-actin mRNA expression and quantified by the $2^{-}$ $\Delta \Delta \mathrm{CT}$ method [23]. Reactions were performed in a $25 \mu \mathrm{l}$ volume, and each sample was run at least in duplicate.

Table 1 Primers used in RT-qPCR

\begin{tabular}{|c|c|}
\hline Primer name & Sequence $\left(5^{\prime}-3^{\prime}\right)$ \\
\hline \multirow[t]{2}{*}{ |L-38 } & Forward: GTGAACATCGAGGACCTATACAAG \\
\hline & Reverse: TCAGTATGGGTGGAGGGTTC \\
\hline \multirow[t]{2}{*}{ IL-36R } & Forward: TGCTTCTGCTTTTCGTGGCAGCA \\
\hline & Reverse: GCCCCGTTTGTTTCTGGCGG \\
\hline \multirow[t]{2}{*}{ IFN- $\gamma$} & Forward: CTCAAGTGGCATAGATGTGGAAG \\
\hline & Reverse: GCTGGACCTGTGGGTTGTTGA \\
\hline \multirow[t]{2}{*}{ |L-17 } & Forward: CTGTGTCTCTGATGCTGTT \\
\hline & Reverse:TGGAACGGTTGAGGTAGT \\
\hline \multirow[t]{2}{*}{ TNF-a } & Forward: AGTCCGGGCAGGTCTACTTT \\
\hline & Reverse: TTGGACCCTGAGCCATAATC \\
\hline \multirow[t]{2}{*}{ IL-6 } & Forward: CCAGAAACCGCTATGAAGTTCC \\
\hline & Reverse: TTGTCACCAGCATCAGTCCC \\
\hline \multirow[t]{2}{*}{ T-bet } & Forward: AGCAAGGACGGCGAATGTT \\
\hline & Reverse: GTGGACATATAAGCGGTTCCC \\
\hline \multirow[t]{2}{*}{ RORyt } & Forward:TGCGACTGGAGGACCTTCTAC \\
\hline & Reverse:TCACCTCCTCCCGTGAAAAG \\
\hline \multirow[t]{2}{*}{ CVB3 } & Forward: CGGTACCTTTGTGCGCCTGT \\
\hline & Reverse: CAGGCCGCCAACGCAGCC \\
\hline \multirow[t]{2}{*}{$\beta$-actin } & Forward: AATTCCATCATGAAGTGTGA \\
\hline & Reverse: ACTCCTGCTTGCTGATCCAC \\
\hline
\end{tabular}

\section{Plaque-forming assay}

Plaque-forming assays and viral titers were performed using standard methods. A portion of heart tissue was weighed and then homogenized in $2 \mathrm{ml}$ of sterile PBS, followed by three freeze/thaw cycles to lyse the cells and release the virus. After spinning at $450 \times g$ for $10 \mathrm{~min}$, the supernatants were sequentially 10-diluted in RPMI 1640 medium. Virus-containing supernatants were overlaid on HeLa cell monolayers and incubated for $1 \mathrm{~h}$ at $5 \%$ $\mathrm{CO}_{2}, 37^{\circ} \mathrm{C}$, in six-well plates. Cells were then washed 3 times with PBS and covered with $2 \mathrm{ml} 0.4 \%$ agar containing RPMI 1640 and 10\% FBS. To allow counting of the plaques, the cell monolayers were fixed and stained after 3 days of incubation. The viral titers were calculated as PFU per organ weight (in grams).

\section{Cytokine assay}

The serum samples were obtained by centrifugation. The level of IL-38 in mouse serum was detected by using a Mouse IL-38 ELISA kit (SND-M144, Chuzhou Shinuoda Biological Technology Co., Ltd., Anhui, China), and the levels of IFN- $\gamma$, IL-17, TNF- $\alpha$, and IL- 6 in serum were detected by Mouse ELISA kits (ExCell Biology Inc., Shanghai, China) according to the instructions provided by the manufacturer. The lowest detectable concentrations of IL-38, IFN- $\gamma$, IL-17, TNF- $\alpha$, and IL- 6 were 7.5, $4,7,7$, and $7 \mathrm{pg} / \mathrm{ml}$, respectively. No significant crossreactivity or interference was observed. All samples were measured in triplicate, and the mean value was calculated.

\section{Statistical analysis}

Data are expressed as mean \pm SD. Statistical analysis of data was performed by unpaired 2-tailed $t$-test or oneway ANOVA, as indicated. The difference in cardiac pathological scores was performed by the Mann-Whitney $U$ test. Survival was estimated using the KaplanMeier method, and the difference in survival was compared by the log-rank test. Correlation between variables was determined by the Spearman rank test. All data were analyzed with GraphPad Prism 8 software (GraphPad Software, La Jolla, CA, USA). $P<0.05$ was considered statistically significant.

\section{Results}

\section{Assessment of AVMC severity}

All mice in the control group grew normally without any apparent behavioral abnormalities. Starting on day 2, CVB3-treated mice showed the symptoms of AVMC, including weakness, coat ruffling, back arching, loss of appetite, fatigue, weight loss, and even death. The 7-day survival rates of mice after CVB3 infection were 
monitored. A total of 13 out of 18 (72.22\%) mice survived in the AVMC group. In detail, a total of $1,2,1$, and 1 mice died on day $3,4,5,6$ post-infection in the AVMC group, respectively. In contrast, none of the mice died in the control group (Fig. 1A). The bodyweights of AVMC mice significantly decreased compared to control mice from day 3 to day 7 (Fig. 1B, all $P<0.01$ ). In addition, the values of heart weight/bodyweight $(\mathrm{HW} / \mathrm{BW})$ and cardiac pathological scores of heart sections in AVMC mice were dramatically higher than those of control mice on day 7 (Fig. $1 \mathrm{C}-\mathrm{E}, \mathrm{P}<0.05$ or $P<0.01$ ).

\section{Elevated expression of IL-38 and IL-36R in AVMC}

On day 7 post-infection, the protein and mRNA expression levels of IL-38 were enhanced in the myocardium of AVMC mice, compared to those of control mice (Fig. 2A, $\mathrm{B}$ and $\mathrm{D}$, both $P<0.01$ ). As shown in Fig. $2 \mathrm{C}$, the markedly increased level of circulating IL-38 protein was also observed in the AVMC group compared to that in the control group $(P<0.01)$. Furthermore, the cardiac relative mRNA expression of IL-36R, the specific receptor of IL-38, was significantly elevated in the AVMC group compared to that in the control group (Fig. 2D, $P<0.01$ ).

\section{Association between IL-38 expression and the severity of AVMC}

To explore the potential role of IL-38 in the pathogenesis of AVMC, we examined the association of IL-38 levels with disease severity, including bodyweight loss and cardiac pathological scores on day 7 post-infection. As shown in Fig. 2E-F, cardiac IL-38 mRNA expression was negatively correlated with bodyweight loss $(\mathrm{r}=-0.714$, $P=0.008)$ and cardiac pathological scores $(\mathrm{r}=-0.600$, $P=0.033$ ). Meanwhile, similar results were obtained for the serum IL-38 levels (Fig. 2G-H), indicating that IL-38 may play a protective role in CVB3-induced AVMC.
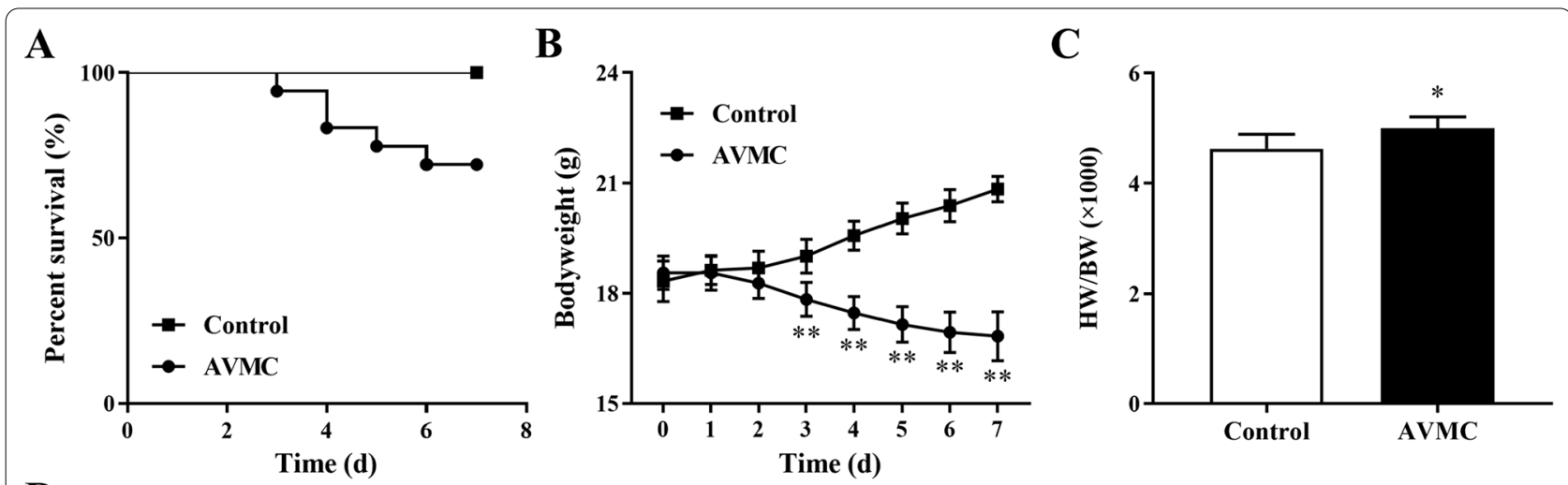

\section{Control}
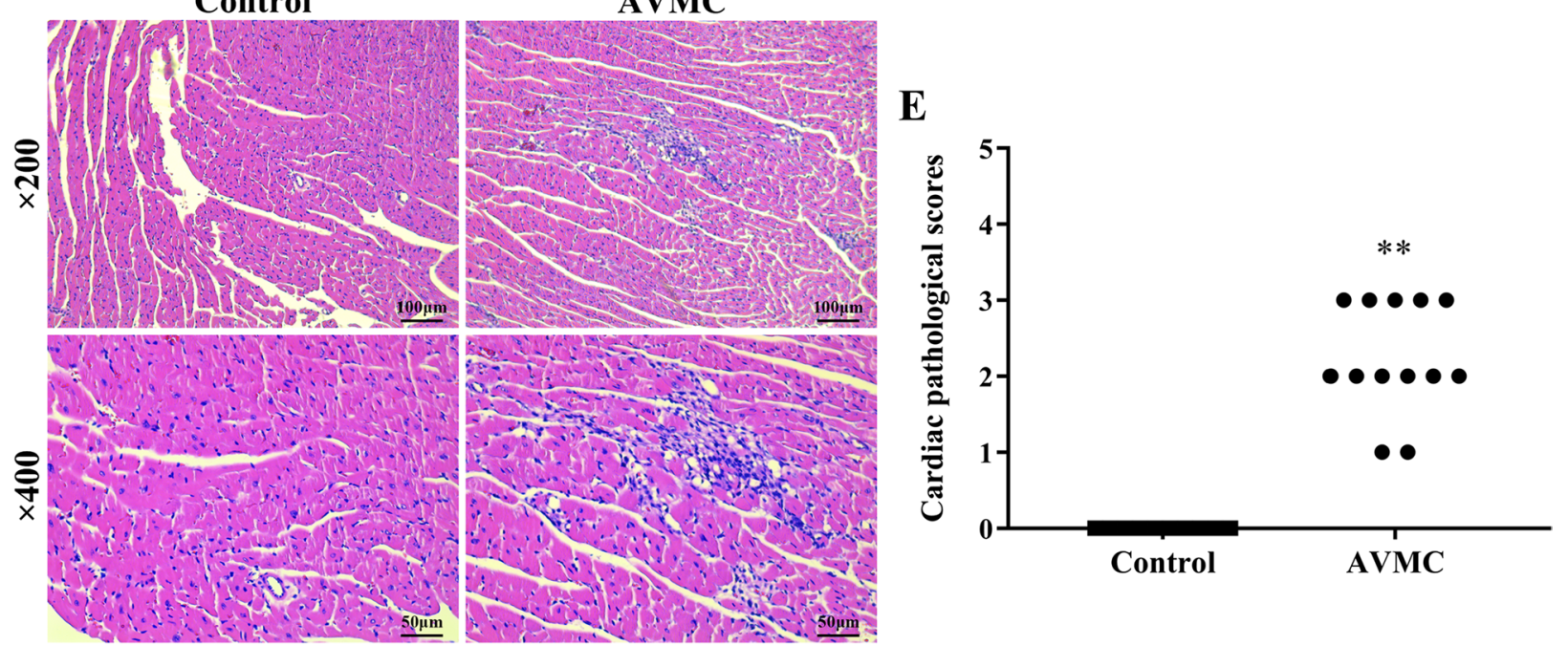

Fig. 1 Assessment of AVMC severity. Male BALB/C mice were infected with CVB3 on day 0. The survival rates (A) and bodyweight changes (B) of mice in the control $(n=10)$ and AVMC $(n=18)$ groups were monitored daily until day 7 . C Values of HW/BW in two groups were recorded on day 7. D Representative images of myocardial histopathology H\&E staining in two groups (magnification $\times 200$ and $\times 400$ ). E Cardiac pathological scores in two groups. Each point represents an individual mouse. ${ }^{*} P<0.05,{ }^{* *} P<0.01$, compared to control group 
A

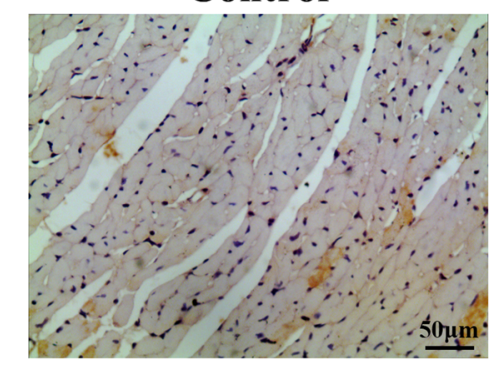

C

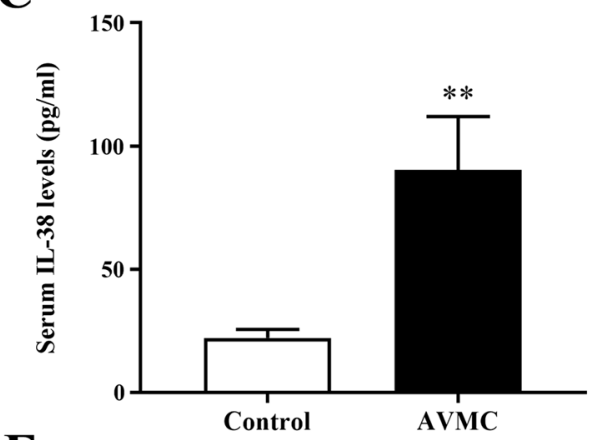

E

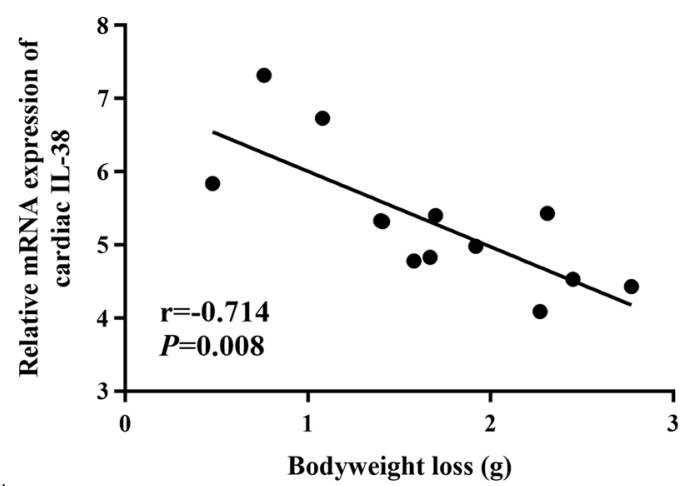

G

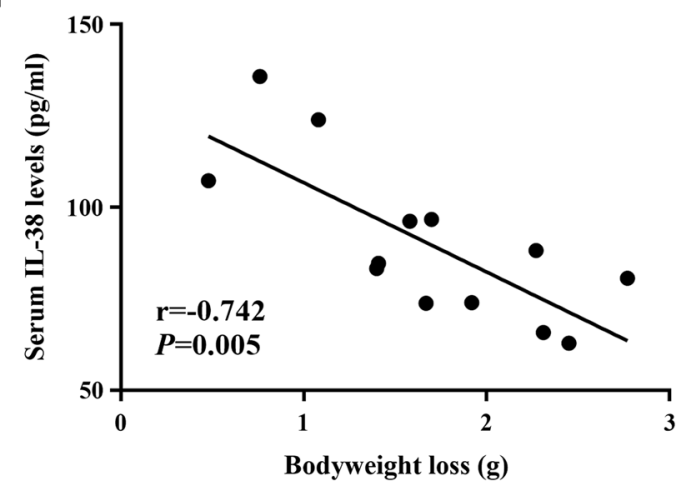

AVMC

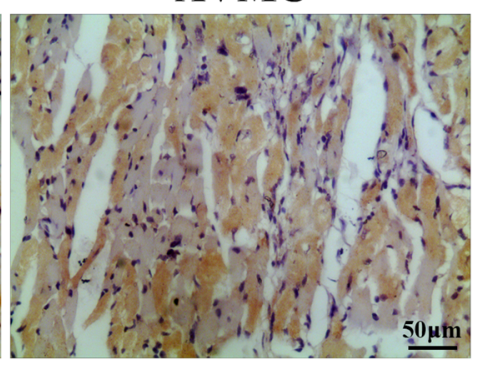

D

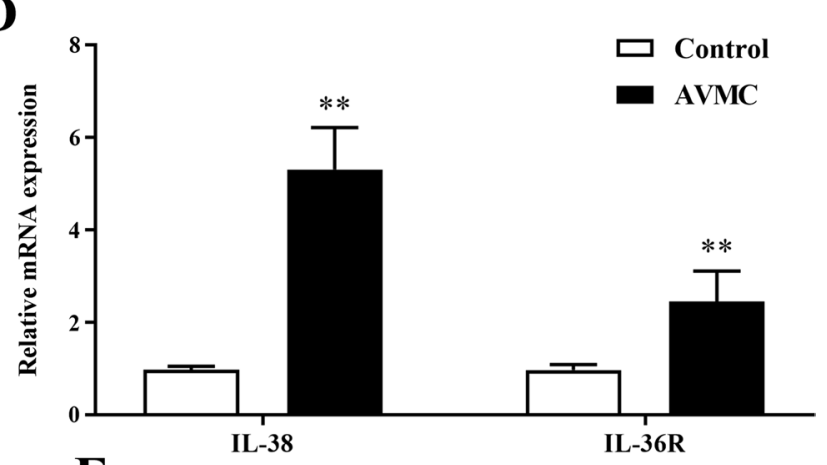

F
B

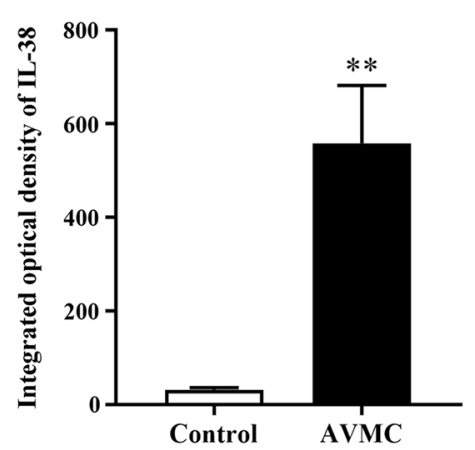

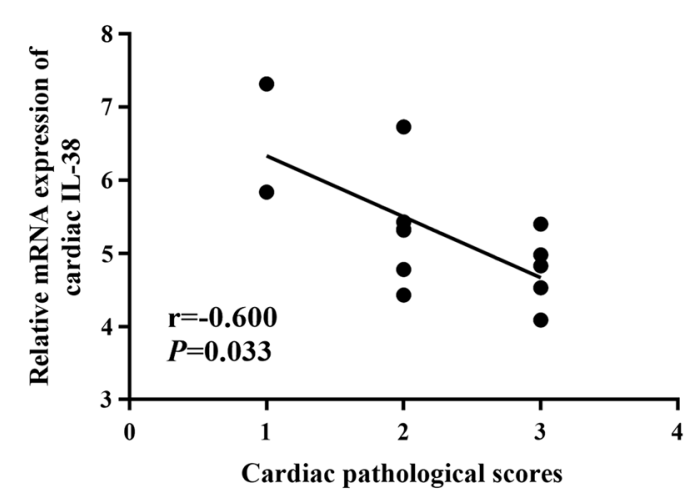

H

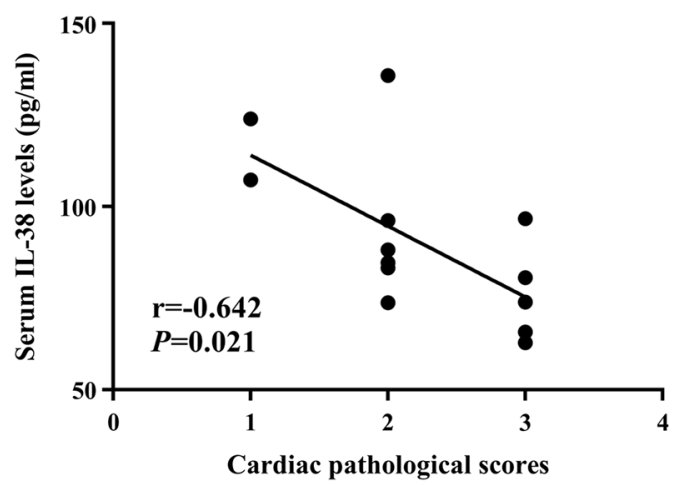

Fig. 2 Elevated expression of IL-38 and IL-36R in AVMC. A Representative images of IL-38 immunohistochemistry of heart tissue from the control $(n=10)$ and AVMC $(n=13)$ groups (Brown granules, magnification $\times 400)$. B Morphometric quantitation of cardiac IL-38 protein expression. C ELISA analysis of serum IL-38 levels. D Relative cardiac mRNA expression of IL-38 and IL-36R detected by RT-qPCR. E-F Negative association of cardiac IL-38 mRNA expression with bodyweight loss and cardiac pathological scores on day 7 post-infection. Each point represents an individual mouse. G-H Negative association of serum IL-38 levels with bodyweight loss and cardiac pathological scores on day 7 post-infection. Each point represents an individual mouse. ${ }^{* *} P<0.01$, compared to control group. Data are expressed as mean $\pm S D$ 


\section{Neutralization of IL-38 reduced survival rate and impaired} cardiac function

We further investigated the protective role of IL-38 against CVB3-induced AVMC by using Mouse AntiIL-38 Abs in vivo. The number of mice surviving to day 7 was $10,11,5$, and 11 for Sham, PBS, IL-38N, and IgG groups, respectively. The 7-day survival rates of the PBS and IgG groups both decreased to $73.33 \%$ $(11 / 15)$, and a marked decline in survival rate $(33.33 \%$,
$5 / 15)$ was observed in the IL-38N group compared to that of the IgG group ( $P=0.037$, Fig. 3A). Meanwhile, mice treated with Anti-IL-38 Abs suffered significant and continuous bodyweight loss from day 3 to day 7 (Fig. 3B, $\mathrm{P}<0.05$ or $P<0.01$ ). To compare cardiac function in different groups, LVESD, LVEDD, FS, and $\mathrm{EF}$ were measured and analyzed by transthoracic echocardiography on day 7. As shown in Fig. 3C-G, compared to $\operatorname{IgG}_{2 \mathrm{~A}}$ isotype control-treated mice, the
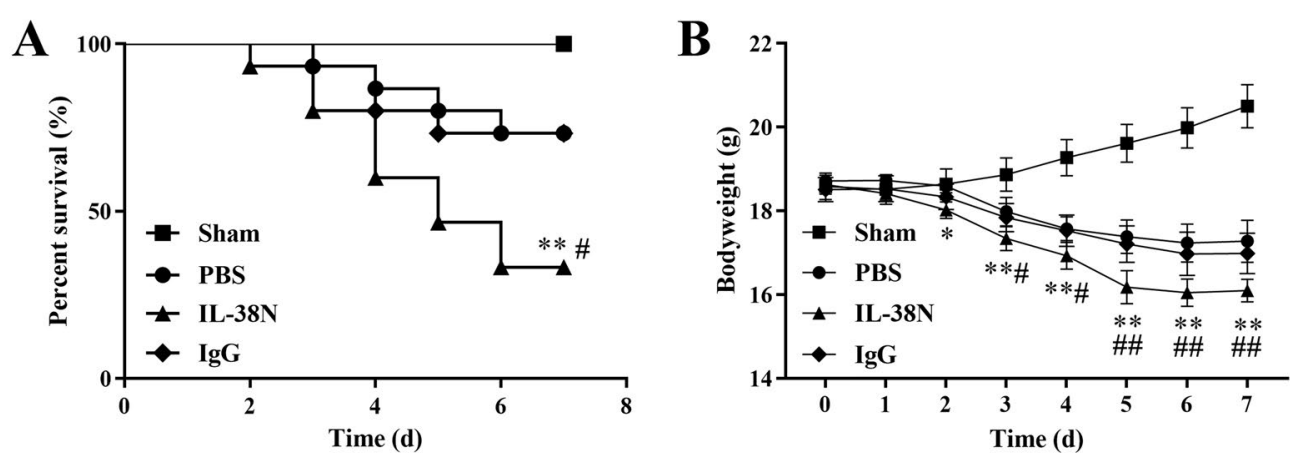

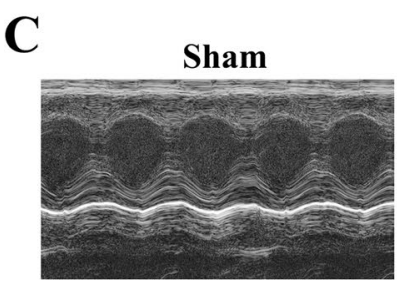

D

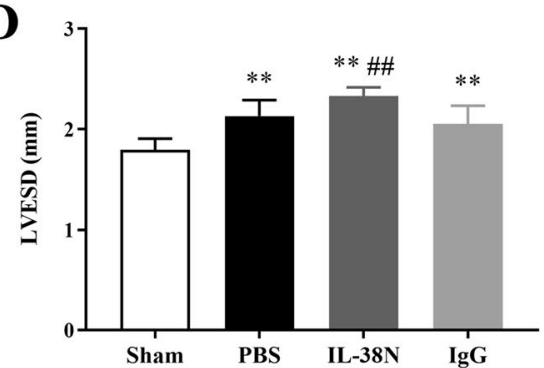

F

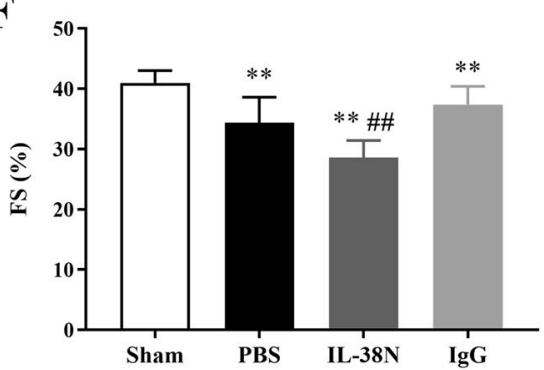

PBS

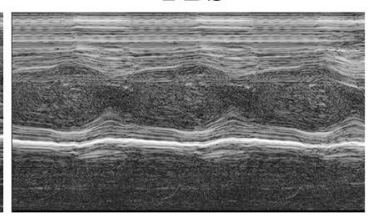

$\mathbf{E}$
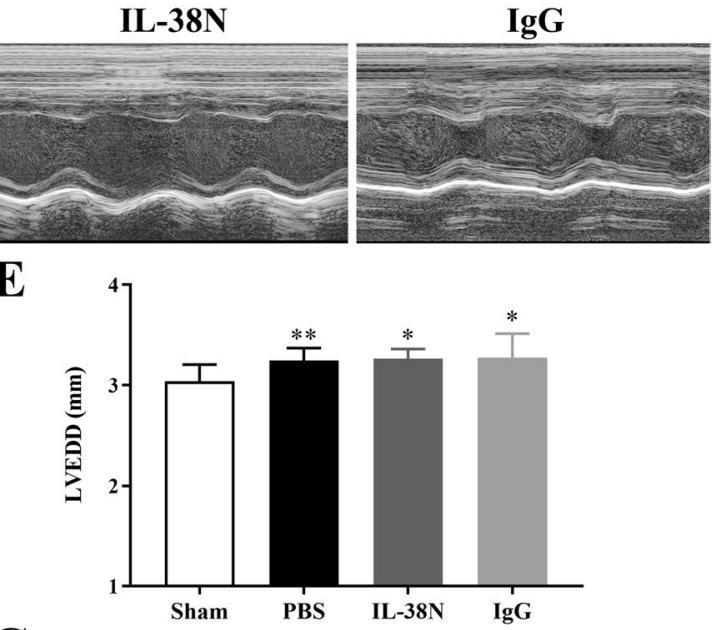

G

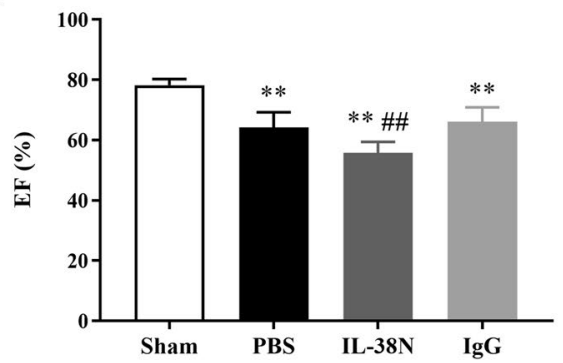

Fig. 3 Neutralization of IL-38 reduced survival rate and impaired cardiac function. Male BALB/C mice were infected with CVB3 on day 0 and then treated with i.p. injection of PBS, Anti-IL-38 Abs, or $\operatorname{lgG}_{2 A}$ isotype control on day 0 and 4 after CVB3 infection. A Survival analysis in the Sham $(n=10), P B S(n=15), I L-38 N(n=15)$, and IgG $(n=15)$ groups after CVB3 infection. B The bodyweight changes were monitored daily until day 7. C Representative M-mode echocardiography images of the left ventricle in different groups on day 7 post-infection. D-G LVESD, LVEDD, FS, and EF were measured on day 7 post-infection. ${ }^{*} P<0.05,{ }^{* *} P<0.01$, compared to Sham group; ${ }^{\#} P<0.05$, ${ }^{\#} P<0.01$, compared to IgG group. Data are expressed as mean \pm SD 
echocardiographic assessment revealed that LVESD was larger, while FS and EF were lower in mice treated with Anti-IL-38 Abs (all $P<0.01)$. There was no statistical difference in LVEDD between the IL-38N and IgG groups (Fig. 3E, $P>0.05$ ). Regarding the survival rates, bodyweight loss, LVESD, LVEDD, FS, and EF, no significant differences were observed between the PBS and IgG groups (all $P>0.05$ ).

\section{Neutralization of IL-38 exacerbated CVB3-induced myocarditis}

As shown in Fig. 4, mice treated with Anti-IL-38 Abs developed more severe myocarditis. Firstly, the values of $\mathrm{HW} / \mathrm{BW}$ in mice treated with Anti-IL-38 Abs were higher than those in the IgG group on day 7 postinfection (Fig. 4A. $P<0.01$ ). Additionally, the cardiac pathological scores of heart section in mice receiving Anti-IL-38 Abs were significantly increased compared to those in the IgG group (Fig. $4 \mathrm{~B}-\mathrm{C}, P<0.05)$. There were no significant statistical differences between the PBS and
IgG groups regarding the values of $\mathrm{HW} / \mathrm{BW}$ and cardiac pathological scores (both $P>0.05$ ).

\section{Neutralization of IL-38 regulated Th1 and Th17 cells differentiation in vivo}

Previous studies have suggested that Th cells differentiation and their production of cytokines, such as IFN- $\gamma$ producing Th1 cells and IL-17-producing Th17 cells, are involved in the pathogenesis of AVMC [7-9]. Moreover, there is growing evidence that IL-38 can mediate an effective immune response via the regulation of Th cells differentiation [12, 24]. Therefore, the percentages of splenic Th1 and Th17 cells, and the mRNA expression levels of master transcription factors (T-bet and ROR $\gamma \mathrm{t}$ ) in myocardium were measured on day 7 post-infection. As shown in Fig. 5, the percentages of splenic Th1 and Th17 cells, and cardiac mRNA expression levels of T-bet and RORyt were markedly increased in the PBS, IL-38N, and IgG groups compared to those in the Sham group (all $P<0.01$ ). Furthermore, compared to those in the IgG group, the percentages of Th1 cells in the IL-38N group were significantly diminished (Fig. 5A-B, $P<0.05$ ),

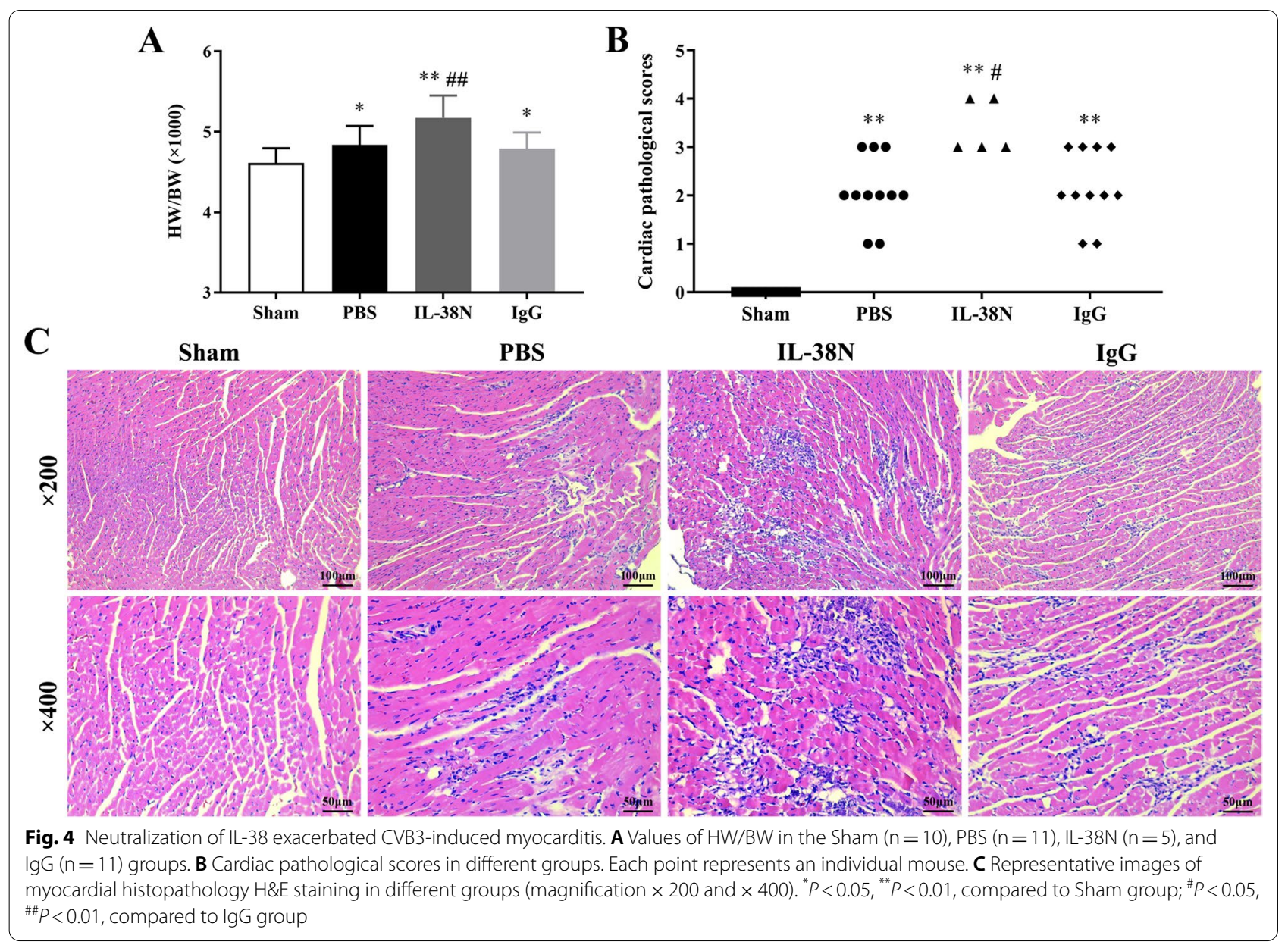




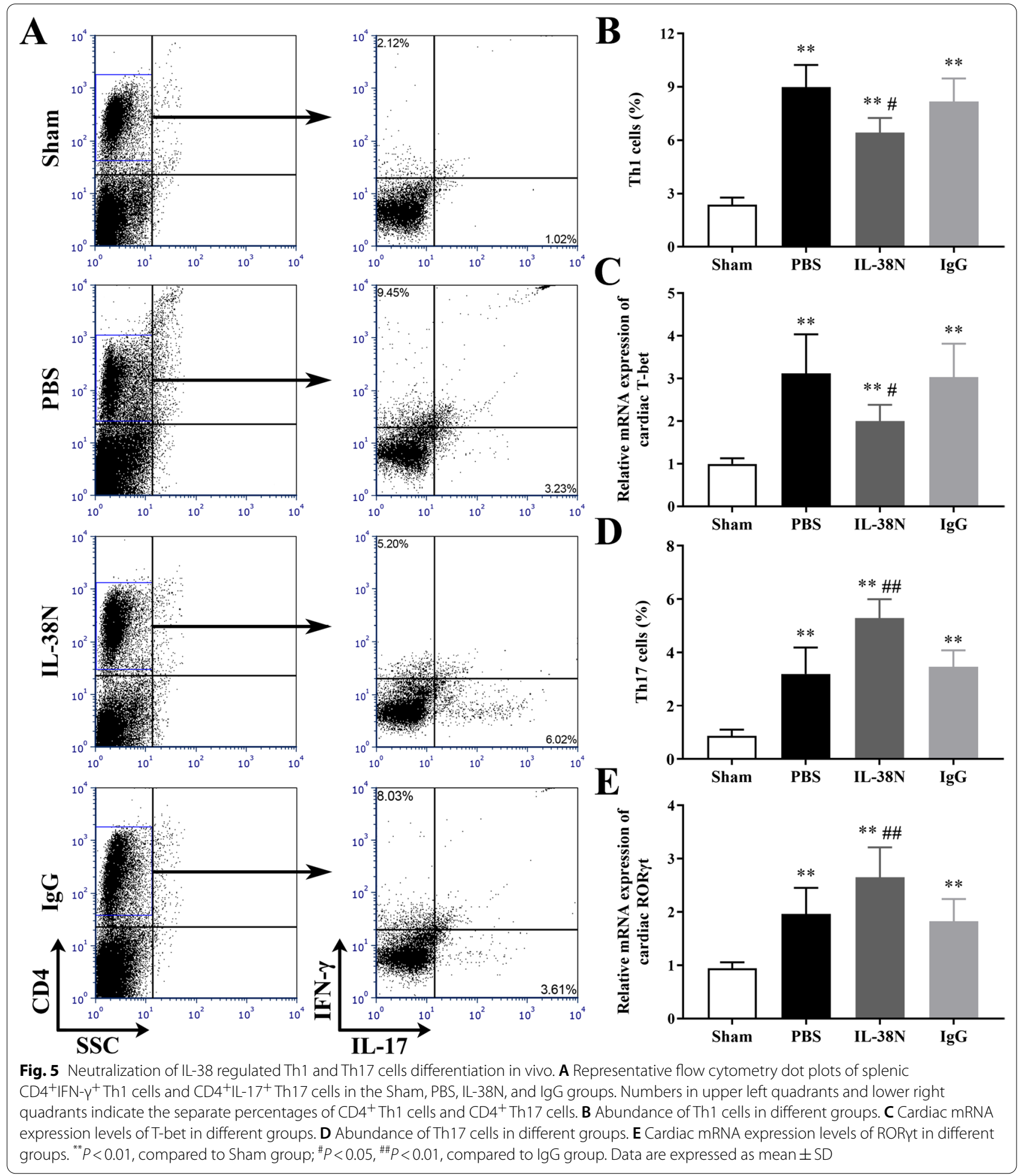

whereas the percentages of Th17 cells were significantly elevated (Fig. 5A and D, $P<0.01$ ). Similarly, cardiac mRNA expression level of T-bet associated with Th1 cells was decreased in the IL-38N group compared to that in the IgG group, whereas ROR $\gamma \mathrm{t}$ associated with Th17 cells was increased (Fig. 5C and E, $P<0.05$ or $P<0.01$ ). No significant differences in the percentages of Th1/Th17 cells and the expression levels of transcription factors were observed between the PBS and IgG groups (all $P>0.05$ ). 
Neutralization of IL-38 reduced IFN- $\gamma$ production, increased IL-17, TNF- $a$, and IL- 6 levels, and promoted CVB3 replication

Cardiac mRNA expression levels of Th1-related cytokine (IFN- $\gamma$ ) and Th17-related cytokines (IL-17, TNF- $\alpha$, and IL-6) were detected by RT-qPCR. Additionally, serum protein levels of these cytokines were measured by ELISA. The mRNA and protein expression levels of IFN- $\gamma$, IL-17, TNF- $\alpha$, and IL- 6 were markedly higher in the PBS, IL-38N, and IgG groups than those in the Sham group (Fig. 6A-D, all $P<0.01$ ). Compared to those in the IgG group, the mRNA and protein expression levels of IL-17, TNF- $\alpha$, and IL- 6 were significantly increased in the IL-38N group, in contrast to the levels of IFN- $\gamma$, which were decreased (Fig. 6A$\mathrm{D}, P<0.05$ or $P<0.01$ ). Moreover, cardiac CVB3 RNA levels and CVB3 titers in the IL-38N group were significantly elevated compared to those in the IgG group (Fig. 6E-F, all $P<0.01$ ). No significant differences in the levels of these cytokines and CVB3 replication were detected between the PBS and IgG groups (all $P>0.05$ ).

\section{Discussion}

IL-38 has been considered as an IL-1 family antagonist for its high homology to IL-36Ra and IL-1Ra [10]. Most studies conclude that IL-38 exerts anti-inflammatory effects in several autoimmune diseases, including RA, AA, and SLE [13-15]. On the contrary, several other studies have shown that IL-38 can act as a pro-inflammatory factor, and it can modestly enhance candida-induced IL-22 and IL-17 expression in human PBMCs at a higher concentration [12, 25]. Truncated IL-38 and mature IL-38 have an anti-inflammatory effect, whereas full-length IL-38 needs to be cleaved in an apoptosis environment to exert its anti-inflammatory effect [26]. However, it has also been reported that knocking out IL-38 does not cause changes in pro-inflammatory cytokines and has no effect on imiquimod-induced psoriasis in mice [27]. Therefore, IL-38 can have pro-inflammatory or anti-inflammatory properties that are likely dependent on its concentration, form, and local environment. Its functional role in CVB3-induced AVMC, if any, is hence unclear. In this study, we provide, for the first time, evidence of significant elevation in cardiac mRNA expression and protein

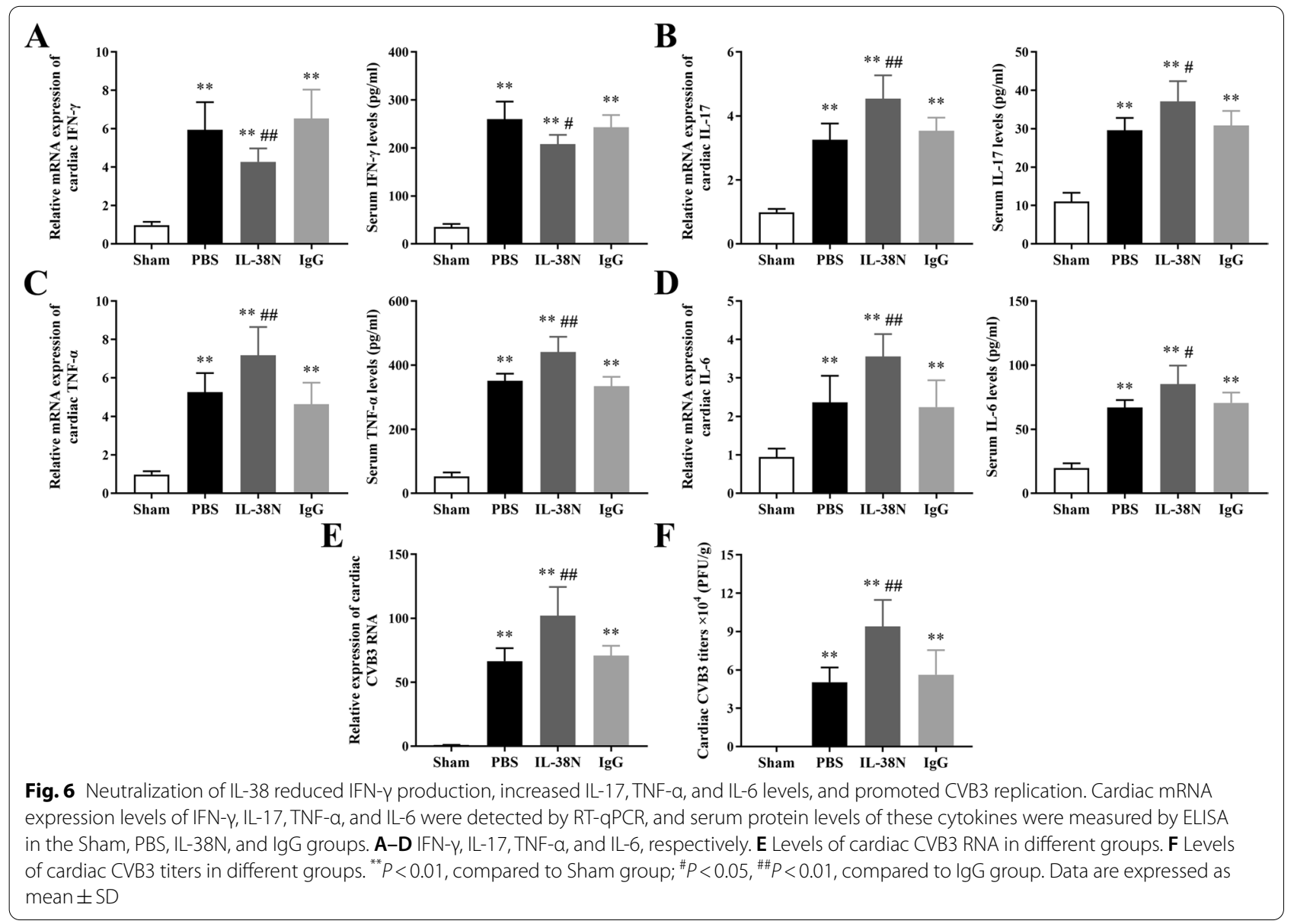


levels of IL-38, and serum IL-38 protein in AVMC. Cardiac mRNA expression of IL-36R, the specific receptor of IL-38, was also markedly up-regulated after CVB3 infection. Moreover, it is noteworthy that the increased IL-38 levels in myocardium and serum were negatively correlated with the severity of AVMC, suggesting that IL-38 may act as a protective agent against AVMC. Further research on IL-38 will help shed new light on the pathogenesis of AVMC.

Based on the observation that the levels of IL-38 and IL-36R were elevated in AVMC, and that the IL-38 levels showed a negative correlation with the severity of AVMC, we tentatively explored the potential role of IL-38 in a mouse model of AVMC with the use of Anti-IL-38 Abs in vivo. Our experimental results demonstrated that neutralization of IL-38 exacerbated the severity of AVMC, as verified by the lower survival rate, impaired cardiac function, continuous bodyweight loss, and higher values of HW/BW and cardiac pathological scores. Aberrant IL-38 expression has been reported in many organs and tissues, such as skin, spleen, placenta, tonsil, thymus, and salivary gland [11]. However, reports concerning the expression and function of IL-38 in inflammatory myocardial diseases remain scarce so far. Previous studies have shown that IL-38 can be a predictor of successful reperfusion and a diagnostic and prognostic marker in patients with myocardial infarction (MI) [28]. Recently, Wei and colleagues demonstrated that inflamed cardiomyocytes and infiltrated macrophages are the main cellular source of IL-38, and that IL-38 plays a protective effect in ventricular remodeling in mice with MI [29]. These findings, together with ours, suggest that IL-38 may be a novel therapeutic target for the treatment of inflammatory myocardial diseases.

In the early stage of CVB3 infection, direct viral invasion causes cardiomyocytes necrosis/apoptosis, which induces the infiltration of immune cells and cytokines production to regulate the host immune response. Th1 cells are known to play a crucial immunoregulatory role in both the innate and adaptive immune responses to viral infections, based on the production of IFN- $\gamma$, a broad-spectrum antiviral cytokine [7]. Recent studies indicate that Th17 cells, which secrete the characteristic cytokine IL-17, contribute to cardiac viral replication by inhibiting Th1 cells differentiation via IL-17 signaling and promote an autoimmune response in AVMC through the excessive release of pro-inflammatory cytokines $[8$, 30]. The role of IL-38 in regulating Th1 and Th17 cells responses has not been identified in AVMC. It has been reported that IL-38 exerts a protective role by preventing the activation and function of Th1 and Th17 cells in most inflammatory and autoimmune diseases [11]. However, Chu et al. found that IL-38 treatment attenuates the severity of SLE due to a reduction in Th17 numbers, with no influence on Th1 cells in mice [31]. Thus, it seems that the regulatory role of IL-38 on Th1 and Th17 cells is not entirely consistent across different disease models and requires further in-depth investigation. In this study, the infiltration of Th1 and Th17 cells, as well as the levels of related cytokines in myocardium and serum were increased in mice with AVMC. Additionally, the aggravating effect of neutralizing IL-38 on myocarditis was closely associated with Th1/Th17 cells imbalance and related cytokines production during the development of AVMC, which had not been reported before. T-bet and ROR $\gamma \mathrm{t}$ are the master transcription factors in directing differentiation of naïve $\mathrm{CD}_{4}^{+} \mathrm{T}$ cells to $\mathrm{Th} 1$ and Th17 cells, respectively [32]. The present study showed that IL-38 neutralization in vivo suppressed the expression of T-bet but promoted RORyt expression, suggesting that T-bet and RORyt may be the potential targets of IL-38 neutralization in inducing Th1/Th17 cells imbalance. In an in vitro study, Chai et al. demonstrated that Th17 cells differentiation and IL-17 production have no significant changes after the treatment with Anti-IL-38 Abs, while IL-38 recombination protein can significantly decrease percentages of Th17 cells through the suppression of p-STAT3 (another important transcription factor of Th17 cells) [33]. Since there is no expression of IL-38 in mouse $\mathrm{CD}_{4}^{+} \mathrm{T}$ cells, but mouse $\mathrm{CD} 4^{+} \mathrm{T}$ cells display surface expression of IL-36R (IL-38 specific receptor) $[10,11]$, making them capable of receiving the biological signal of IL-38 released by a large number of infiltrated immune cells (e.g., B cells, NK cells, macrophages, and DCs) during the acute phase of infection, this may be an important mechanism by which Anti-IL-38 Abs participate in the regulation of Th cells differentiation in vivo. More specifically, neutralization of IL-38 in the IL-38N group could significantly promote CVB3 replication, which was consistent with the previous observation that IL-38 contributed to resistance to viral infection [16-18], further highlighting an antiviral role for IL-38 in AVMC. We then conclude that IL-38 may play a role in regulating the balance between antiviral immunity and autoimmunity in CVB3-induced AVMC.

To our knowledge, this is the first report of IL-38 being involved in the pathogenesis of AVMC. However, the study has several limitations. First, all experiments were performed exclusively in male mice. Previous studies have shown that female mice are less susceptible to CVB3 infection and less prone to develop severe AVMC than male mice, mainly due to the protective effect of estradiol [34]. Therefore, to simplify the current study, we chose to focus on male mice. Whether Anti-IL-38 Abs have the same effect on AVMC in female mice requires further assessment. Second, it 
has been shown that IL-38 binds to IL-36R and exerts its effects by antagonizing the activation of intracellular signaling pathways such as JNK/AP1, p38 MAPK, ERK1/2, and NF- $\kappa B[14,35]$, which have been widely confirmed to be involved in the pathogenesis of AVMC $[2,5,6]$. Studies on the downstream signaling pathway of IL-38 will help reveal its regulatory mechanisms in AVMC in more detail. Furthermore, recent studies have shown that IL-38 treatment can effectively reduce fibrosis in different animal models $[29,36]$. The potential role of IL-38 in chronic myocarditis and dilated cardiomyopathy is still an interesting open issue.

\section{Conclusions}

In summary, our preliminary data demonstrate that neutralization of IL-38 significantly exacerbated CVB3induced AVMC in mice. Neutralization of IL-38 in vivo resulted in the imbalance of Th1/Th17 cells and increased CVB3 replication. Therefore, our investigation shows that IL-38 may play a myocardium-protective role in AVMC and suggests IL-38 as a potential therapeutic target.

\begin{abstract}
Abbreviations
IL-38: Interleukin-38; AVMC: Acute viral myocarditis; CVB3: Coxsackievirus B3; IL-36R: Interleukin-36 receptor; Abs: Antibodies; Th: T helper; Ra: Receptor antagonist; PBMCs: Peripheral blood mononuclear cells; NK cells: Natural killer cells; DCs: Dendritic cells; RA: Rheumatoid arthritis; AA: Allergic asthma; SLE: Systemic lupus erythematosus; MI: Myocardial infarction; i.p.: Intraperitoneal; PFU: Plaque-forming unit; PBS: Phosphate-buffered saline; LVESD: Left ventricular end-systolic diameter; LVEDD: Left ventricular end-diastolic diameter; FS: Fractional shortening; EF: Ejection fraction; H\&E: Hematoxylin and Eosin; IOD: Integrated optical density; RT-qPCR: Quantitative real-time PCR; HW/BW: Heart weight/bodyweight.
\end{abstract}

\section{Supplementary Information}

The online version contains supplementary material available at https://doi. org/10.1186/s12985-021-01687-w.

Additional file 1: Figure S1. Effects of different doses of Anti-IL-38 Abs on IL-38 expression in vivo. Male BALB/C mice were treated with three different doses of Anti-IL-38 Abs (25, 50, or $75 \mu \mathrm{g}$ per mouse) by i.p. injection on day 0 and day 4 after CVB3 infection. Cardiac mRNA expression levels of IL-38 were detected by RT-GPCR (A), and its protein levels in serum were measured by ELISA (B) on day 7 . Each dose group contained 5 surviving mice. ${ }^{* *} P<0.01$, compared to mice without Anti-IL-38 Abs treatment; ${ }^{\#} P<0.05,{ }^{\# \#} P<0.01$, compared to mice treated with Anti-IL-38 Abs $(25 \mu \mathrm{g}$ per mouse per injection). Data are expressed as mean \pm SD.

\section{Acknowledgements}

We are very thankful to Prof. Weifeng Wu from Guangxi Medical University for providing the Coxsackievirus B3 Nancy strain used in this study. We also thank Jiuyun Zhang and Chong Zhang for administrative and technical assistance.

\section{Authors' contributions}

$Y X, J K$, and FC conceived and designed the experiments; YX, MC, QC, TH, QF, $\mathrm{FL}$, and JK performed the experiments and analyzed the data; $Y X$ participated in data collection and prepared the initial draft of the manuscript; FC coordinated the study and reviewed the manuscript. All authors read and approved the final manuscript.

\section{Funding}

This work was supported by the Youth Scientific Research Project of Fujian Provincial Health Commission (Grant No. 2019-2-1) and the Startup Fund for Scientific Research of Fujian Medical University (Grant No. 2018QH1120).

\section{Availability of data and materials}

The data used to support the findings of this study are included in this current manuscript and its additional files.

\section{Declarations}

\section{Ethics approval and consent to participate}

All animal experiments were performed according to the guidelines for the Care and Use of Laboratory Animals and were approved by the Animal Experimentation Ethics Committee of Shengli Clinical Medical College of Fujian Medical University (SYXK: 2016-0004).

\section{Consent for publication}

Not applicable.

\section{Competing interests}

The authors declare that they have no competing interests.

\section{Author details}

${ }^{1}$ Shengli Clinical Medical College of Fujian Medical University, Fuzhou 350001, Fujian, People's Republic of China. ${ }^{2}$ The Fourth Department of Intensive Care Unit, Fujian Provincial Hospital, Fuzhou 350001, Fujian, People's Republic of China. ${ }^{3}$ Department of Emergency, Fujian Provincial Hospital, Fuzhou 350001, Fujian, People's Republic of China. ${ }^{4}$ Fujian Provincial Key Laboratory of Emergency Medicine, Fuzhou 350001, Fujian, People's Republic of China.

Received: 5 July 2021 Accepted: 1 November 2021

Published online: 14 November 2021

\section{References}

1. Kühl U, Schultheiss HP. Viral myocarditis: diagnosis, aetiology and management. Drugs. 2009;69(10):1287-302. https://doi.org/10.2165/00003 495-200969100-00001.

2. Zheng C, Wu SM, Lian H, Lin YZ, Zhuang R, Thapa S, Chen QZ, Chen YF, Lin JF. Low-intensity pulsed ultrasound attenuates cardiac inflammation of CVB3-induced viral myocarditis via regulation of caveolin-1 and MAPK pathways. J Cell Mol Med. 2019;23(3):1963-75. https://doi.org/10.1111/ jcmm.14098.

3. Poller W, Schultheiss HP, Kühl U. Viruses and other environmental factors as possible sources of phenotypic heterogeneity in familial dilated cardiomyopathy. J Am Coll Cardiol. 2006;47(3):689-90. https://doi.org/10. 1016/j.jacc.2005.11.004

4. Andréoletti L, Lévêque N, Boulagnon C, Brasselet C, Fornes P. Viral causes of human myocarditis. Arch Cardiovasc Dis. 2009;102(6-7):559-68. https://doi.org/10.1016/j.acvd.2009.04.010.

5. Lasrado N, Reddy J. An overview of the immune mechanisms of viral myocarditis. Rev Med Virol. 2020;30(6):1-14. https://doi.org/10.1002/rmv. 2131.

6. Bracamonte-Baran W, Čiháková D. Cardiac autoimmunity: myocarditis. Adv Exp Med Biol. 2017;1003:187-221. https://doi.org/10.1007/978-3319-57613-8 10

7. Fairweather $\bar{D}$, Stafford KA, Sung YK. Update on coxsackievirus B3 myocarditis. Curr Opin Rheumatol. 2012;24(4):401-7. https://doi.org/10.1097/ BOR.0b013e328353372d.

8. Xie Y, Chen R, Zhang X, Yu Y, Yang Y, Zou Y, Ge J, Chen H, Garzino-Demo A Blockade of interleukin-17A protects against coxsackievirus B3-induced myocarditis by increasing COX-2/PGE2 production in the heart. FEMS Immunol Med Microbiol. 2012;64(3):343-51. https://doi.org/10.1111/j. $1574-695 \times .2011 .00918 \times$. 
9. Li L, Li L, Xiao L, Shangguan J. Progranulin ameliorates coxsackievirusB3-induced viral myocarditis by downregulating Th1 and Th17 cells. Exp Cell Res. 2018;367(2):241-50. https://doi.org/10.1016/j.yexcr.2018.04.001.

10. Bensen JT, Dawson PA, Mychaleckyj JC, Bowden DW. Identification of a novel human cytokine gene in the interleukin gene cluster on chromosome 2q12-14. J Interferon Cytokine Res. 2001;21(11):899-904. https:// doi.org/10.1089/107999001753289505.

11. Yuan X, Peng X, Li Y, Li M. Role of IL-38 and its related cytokines in inflammation. Mediators Inflamm. 2015;2015: 807976. https://doi.org/10.1155/ 2015/807976.

12. van de Veerdonk FL, Stoeckman AK, Wu G, Boeckermann AN, Azam T, Netea MG, Joosten LA, van der Meer JW, Hao R, Kalabokis V, Dinarello CA. IL-38 binds to the IL-36 receptor and has biological effects on immune cells similar to IL-36 receptor antagonist. Proc Natl Acad Sci USA. 2012;109(8):3001-5. https://doi.org/10.1073/pnas.1121534109.

13. Xu WD, Su LC, He CS, Huang AF. Plasma interleukin-38 in patients with rheumatoid arthritis. Int Immunopharmacol. 2018;65:1-7. https://doi.org/ 10.1016/j.intimp.2018.09.028.

14. Sun X, Hou T, Cheung E, lu TN, Tam VW, Chu IM, Tsang MS, Chan PK, Lam CW, Wong CK. Anti-inflammatory mechanisms of the novel cytokine interleukin-38 in allergic asthma. Cell Mol Immunol. 2020;17(6):631-46. https://doi.org/10.1038/s41423-019-0300-7.

15. Xu WD, Su LC, Liu XY, Wang JM, Yuan ZC, Qin Z, Zhou XP, Huang AF. IL-38: A novel cytokine in systemic lupus erythematosus pathogenesis. J Cell Mol Med. 2020;24(21):12379-89. https://doi.org/10.1111/jcmm.15737.

16. Wang HJ, Jiang YF, Wang XR, Zhang ML, Gao PJ. Elevated serum interleukin-38 level at baseline predicts virological response in telbivudinetreated patients with chronic hepatitis B. World J Gastroenterol. 2016;22(18):4529-37. https://doi.org/10.3748/wjg.v22.i18.4529.

17. Gao X, Chan PKS, Lui GCY, Hui DSC, Chu IM, Sun X, Tsang MS, Chan BCL, Lam CW, Wong CK. Interleukin-38 ameliorates poly(l:C) induced lung inflammation: therapeutic implications in respiratory viral infections. Cell Death Dis. 2021;12(1):53. https://doi.org/10.1038/s41419-020-03283-2.

18. Conti P, Ronconi G, Caraffa A, Gallenga CE, Ross R, Frydas I, Kritas SK. Induction of pro-inflammatory cytokines (IL-1 and IL-6) and lung inflammation by Coronavirus-19 (COVI-19 or SARS-CoV-2): anti-inflammatory strategies. J Biol Regul Homeost Agents. 2020;34(2):327-31. https://doi. org/10.23812/CONTI-E.

19. Ge Y, Huang M, Wu Y, Dong N, Yao YM. Interleukin-38 protects against sepsis by augmenting immunosuppressive activity of CD4 ${ }^{+} \mathrm{CD} 25^{+}$ regulatory T cells. J Cell Mol Med. 2020;24(2):2027-39. https://doi.org/10. 1111/jcmm.14902.

20. Xu F, Lin S, Yan X, Wang C, Tu H, Yin Y, Cao J. Interleukin 38 protects against lethal sepsis. J Infect Dis. 2018;218(7):1175-84. https://doi.org/10. 1093/infdis/jiyz289.

21. Respress JL, Wehrens XH. Transthoracic echocardiography in mice. J Vis Exp. 2010;39:1738. https://doi.org/10.3791/1738.

22. Grabie N, Delfs MW, Westrich JR, Love VA, Stavrakis G, Ahmad F, Seidman CE, Seidman JG, Lichtman AH. IL-12 is required for differentiation of pathogenic CD8+ T cell effectors that cause myocarditis. J Clin Invest. 2003;111(5):671-80. https://doi.org/10.1172/JCl16867.

23. Livak KJ, Schmittgen TD. Analysis of relative gene expression data using real-time quantitative PCR and the 2(-Delta Delta C(T)) Method. Methods. 2001;25(4):402-8. https://doi.org/10.1006/meth.2001.1262.

24. Han Y, Mora J, Huard A, da Silva P, Wiechmann S, Putyrski M, Schuster C, Elwakeel E, Lang G, Scholz A, Scholz T, Schmid T, de Bruin N, Billuart P, Sala C, Burkhardt H, Parnham MJ, Ernst A, Brüne B, Weigert A. IL-38 ameliorates skin inflammation and limits IL-17 production from $\gamma \delta$ T cells. Cell Rep. 2019;27(3):835-46.e5. https://doi.org/10.1016/j.celrep.2019.03.082.

25. Boutet MA, Blanchard F, Goff Le. Response B, to: "Does IL-38 act on macrophages and, or dendritic cells in arthritis?" by Jiang, et al. Ann Rheum Dis. 2018;77(3): e13. https://doi.org/10.1136/annrheumdis-2017-211793.

26. Mora J, Schlemmer A, Wittig I, Richter F, Putyrski M, Frank AC, Han Y, Jung M, Ernst A, Weigert A, Brüne B. Interleukin-38 is released from apoptotic cells to limit inflammatory macrophage responses. J Mol Cell Biol. 2016:8(5):426-38. https://doi.org/10.1093/jmcb/mjw006.

27. Palomo J, Troccaz S, Talabot-Ayer D, Rodriguez E, Palmer G. The severity of imiquimod-induced mouse skin inflammation is independent of endogenous IL-38 expression. PLoS ONE. 2018;13(3):e0194667. https://doi.org/ 10.1371/journal.pone.0194667.
28. Zhong Y, Yu K, Wang X, Wang X, Ji Q, Zeng Q. Elevated plasma IL-38 concentrations in patients with acute ST-segment elevation myocardial infarction and their dynamics after reperfusion treatment. Mediators Inflamm. 2015;2015:490120. https://doi.org/10.1155/2015/490120.

29. Wei Y, Lan Y, Zhong Y, Yu K, Xu W, Zhu R, Sun H, Ding Y, Wang Y, Zeng Q. Interleukin-38 alleviates cardiac remodelling after myocardial infarction. J Cell Mol Med. 2020;24(1):371-84. https://doi.org/10.1111/jcmm.14741.

30. Yuan J, Yu M, Lin QW, Cao AL, Yu X, Dong JH, Wang JP, Zhang JH, Wang M, Guo HP, Cheng X, Liao YH. Th17 cells contribute to viral replication in coxsackievirus B3-induced acute viral myocarditis. J Immunol. 2010;185(7):4004-10. https://doi.org/10.4049/jimmunol.1001718.

31. Chu M, Tam LS, Zhu J, Jiao D, Liu H, Cai Z, Dong J, Kai Lam CW, Wong CK. In vivo anti-inflammatory activities of novel cytokine IL-38 in Murphy Roths Large (MRL)/lpr mice. Immunobiology. 2017;222(3):483-93. https:// doi.org/10.1016/j.imbio.2016.10.012.

32. Yu F, Sharma S, Edwards J, Feigenbaum L, Zhu J. Dynamic expression of transcription factors T-bet and GATA-3 by regulatory T cells maintains immunotolerance. Nat Immunol. 2015;16(2):197-206. https://doi.org/10. 1038/ni.3053

33. Chai YS, Lin SH, Zhang M, Deng L, Chen Y, Xie K, Wang CJ, Xu F. IL-38 is a biomarker for acute respiratory distress syndrome in humans and downregulates Th17 differentiation in vivo. Clin Immunol. 2020;210: 108315. https://doi.org/10.1016/j.clim.2019.108315.

34. Huber SA. Coxsackievirus B3-induced myocarditis: infection of females during the estrus phase of the ovarian cycle leads to activation of T regulatory cells. Virology. 2008;378(2):292-8. https://doi.org/10.1016/j. virol.2008.05.015.

35. Esmaeilzadeh A, Pouyan S, Erfanmanesh M. Is Interleukin-38 a key player cytokine in atherosclerosis immune gene therapy? Med Hypotheses. 2019;125:139-43. https://doi.org/10.1016/j.mehy.2019.02.048.

36. Xu Z, Yuan X, Gao Q, Li Y, Li M. Interleukin-38 overexpression prevents bleomycin-induced mouse pulmonary fibrosis. Naunyn Schmiedebergs Arch Pharmacol. 2021;394(2):391-9. https://doi.org/10.1007/ s00210-020-01920-3.

\section{Publisher's Note}

Springer Nature remains neutral with regard to jurisdictional claims in published maps and institutional affiliations.

Ready to submit your research? Choose BMC and benefit from:

- fast, convenient online submission

- thorough peer review by experienced researchers in your field

- rapid publication on acceptance

- support for research data, including large and complex data types

- gold Open Access which fosters wider collaboration and increased citations

- maximum visibility for your research: over $100 \mathrm{M}$ website views per year

At BMC, research is always in progress.

Learn more biomedcentral.com/submissions 